
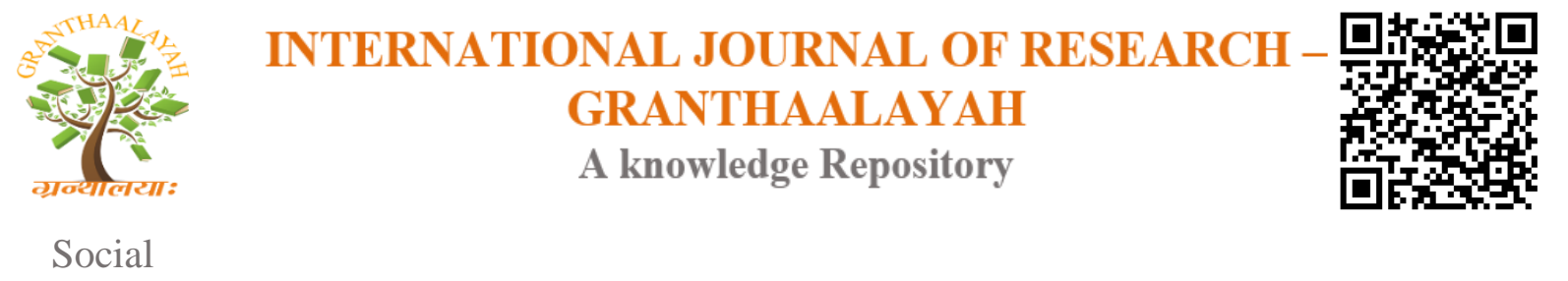

\title{
EFFECT OF YOGA PERSONALITY DEVELOPMENT CAMP ON TRIDOSHAS IN CHILDREN
}

\author{
SP Suchitra ${ }^{* 1}$, HR Nagendra ${ }^{2}$ \\ ${ }^{* 1}$ MSc (Yoga), MA (Child mental health), Swami Vivekananda Yoga Anusandhana Samsthana \\ university, Bangalore, India \\ ${ }^{2} \mathrm{PhD}$, Vice Chancellor, Swami Vivekananda Yoga Anusandhana Samsthana Yoga University, \\ Bangalore, India
}

\begin{abstract}
Background: Yoga has proven effect on personality and psychological disturbances in children. But no studies are available on short term effect of Yoga on Tridoshas, which may point to restoration of positive health.

Objective: To understand the effect of Yoga Personality Development Camp on the tridoshas in children.

Method: The study was pre-post design with control. 320 children (160 children in each group), aged 8-12 yrs, selected from a residential camp at Prashanti kutiram Jigani (experimental group) and Jayagopal Garodia Rasrtothana school. Experimental group children practiced Integral Yoga module including Asanas, pranayama, nadanusandhana, chanting, and games. Control group children observed were not given any intervention. Caraka Child personality inventory was administered before and after 10 days. Mann-Whitney U test and Wilcoxon Signed Ranks Test were applied.

Results: Vata decreased significantly, while Pitta and Kapha increased significantly as compared to the control group.

Conclusions: Yoga Personality Development camp has the significant effect on the tridoshas (Vata,Pitta and Kapha) in Children.

Keywords: Tridosha; Prakriti; Vāta; Pitta; Kapha.

Cite This Article: SP Suchitra, and HR Nagendra. (2019). "EFFECT OF YOGA PERSONALITY DEVELOPMENT CAMP ON TRIDOSHAS IN CHILDREN." International Journal of Research - Granthaalayah, 7(1), 342-347. 10.29121/granthaalayah.v7.i1.2019.1061.
\end{abstract}

\section{Introduction}

Accoridng to Ayurveda, Tridosha (metabolic principles- Vāta, Pitta, Kapha) and trigunas (Sattva. Rajas, Tamas-representing harmony, passion, ignorance) forms basis of the personality. Āyurveda classics illustrate 7 types of Doshaja Prakrti and sixteen types of mental constitution formed at the time of conception ${ }^{1-3}$. Accordingly, they affirm persons with predominance of single Dosha, and 
two Dosha are susceptible to somatic diseases and psychological illness. Importance of tridoshas has been postulated ${ }^{4}$. Similarities between Āyurveda concept and modern gestalt theory and the correspondence of 16 types of personalities with 16 types of psychological disorders have been discussed $^{5}$.

Mindfulness training through yoga has reduced stress in school age children ${ }^{6}$. Kripalu yoga training has shown preventive benefits in psychosocial wellbeing when compared to physical excercises ${ }^{7}$. Studies regarding exercise effects on overweight, growth, chronic illness, depression and anxiety in children and adolescents are reviewed ${ }^{8}$. Slow and fast suryanamaskara are compared in children ${ }^{9}$. Efficacy of a movement based, modified RR program, involving yoga and dance in treating behavioral and some core features of autism has been examined ${ }^{10}$. An executive function in children has been improved by yoga ${ }^{11}$.

Immediate effect of yoga relaxation techniques on attention in children is been reported ${ }^{12}$. Imitation skills in children with autism spectrum have been increased by integrated yoga therapy ${ }^{13}$. Randomized controlled studies which investigated the efficacy of mediation therapy in children and adults diagnosed with ADHD have been discussed ${ }^{14}$. Individualized yoga therapy has been proven as adjunctive therapy for eating disorders in children ${ }^{15}$. Effect of breathing exercises on respiratory parameters in children has been studied ${ }^{16}$. Six-month yoga training has improved muscle power, dexterity and visual perception in girls ${ }^{17}$. Pranayama effects on grip strength and spatial memory have been reported.

The GES educational program, based around integrated yoga modules is proven effective in enhancing visual and spatial memory ${ }^{18}$. Relaxation and yoga exercise have reduced anxiety of children and adolescent group ${ }^{19}$. The efficacy of integral yoga module as an effective therapeutic tool in the management of mentally retarded children has been proven ${ }^{20}$. A study has proved reduction of somatic stress by muscle relaxation ${ }^{21}$. Higher scores in life satisfaction and lower scores in excitability, aggressiveness, openness, emotionality and somatic complaints was followed by hatha-yoga practice ${ }^{22}$

A study has reported significant changes in Sattva, Rajas, Tamas by integral yoga practice on subjects of age group -17-63 23 . A randomized controlled study has shown the influence of Yoga on Gunas and self-esteem in comparison to physical exercise ${ }^{24}$.Another study has reported changes in wellbeing of children after yoga $\mathrm{a}^{25}$

A pilot study has observed significant changes in tridoshas after three months of yoga practice in children $^{26}$. As there were no studies available on the effect of Yoga Personality Development Camp on tridoshas need was felt for the present study to be carried out.

\section{Methods}

The study was pre - post design with control group. Yoga group children attended ten days Yoga Personality Development Camp. Caraka child personality inventory (In peer review) was administered at the beginning, and at the end of ten days. Vata,Pitta,Kapha mean scores were analyzed. SPSS (16.0) was use dfor the statistical analysis. Kolomogorov-Smirnov test was applied to check normal distribution of the data. Within group significance was analyzed by using 
Wilcoxon Signed Ranks Test and between group significance was analyzed by Mann-Whitney U test.

Caraka child personality inventory which was based on Sanskrit verses quoted in nine texts and content validity by Ayurveda experts and psychologist. It had three subscales- Vata(A), Pitta (B), $\mathrm{Kapha}(\mathrm{C})$ with 26,24 and 27 items respectively. It was associated with good reliability (Cronbach's alpha for A, B and C scales were $0.54,0.64$ and 0.64 respectively and spilt half scores were 0.64. 0.60 And 0.66 respectively. Factor validity coefficient Scores on each item was above 0.3.

160 children (for each group) of the age group 8-12 years from Yoga Personality Development Camp in Prashanti kutiram and Jayagopal Garodia Rastrotthana School Bangalore were included in the study. Children with Attention Deficit Hyperactive Disorder, Autism, Psychosis, who are mentally challenged were excluded from the study. In Yoga group 76 boys and 84 girls were there. Similarly, in control group 82 boys and 78 girls were there. (Table-1)

Yoga practices included Breathing exercises like ankle stretch breathing, hand-stretch breathing, Dog breathing, Rabbit breathing, Dynamic exercises like jogging, forward-backward bending, Surya-namaskara. Asanas like vrkshasana, veerabhadrasana, ustrasana, padahastasana, ostrich pose, blossom. Pavanamuktasana kriya, Pranayama like- nadishuddhi, bhramari, Yogic breathing. Nadanusandhana. Yogic games like search engine, find the leader. Along with ,that stories. Vedic chanting, Bhagavad-Gita chanting.

Table 1: Demographic data

\begin{tabular}{|l|l|l|}
\hline Sample & Yoga & Control \\
\hline Gender & 76 boys/N-160 & 82 boys/N-160 \\
\hline Age & $8-12$ years & $8-12$ years \\
\hline Mean \pm SD & $10.88 \pm 1.08$ & $10.13 \pm 1.23$ \\
\hline
\end{tabular}

Table 1 gives demographics of both groups. In Yoga group 76 boys and 84 girls were there. Similarly, in control group 82 boys and 78 girls were there.

\section{Results}

Yoga group showed significant changes in Vata, Pitta and Kapha after intervention. While in control group there was no significant changes. (Table-2)

Table 2: Mean scores of both group and significance

\begin{tabular}{|l|l|l|l|l|l|l|}
\hline Dosha & Y(pre) & Y(post) & significance & C (pre) & C(post) & Significance \\
\hline Vata & $11.95 \pm 2.74$ & $9.43 \pm 2.41 \dagger$ & $.001^{*}$ & $11.20 \pm 3.22$ & $11.21 \pm 3.18$ & $.782^{*}$ \\
\hline Pitta & $9.50 \pm 3.43$ & $11.16 \pm 3.12 \dagger$ & $.001^{*}$ & $10.26 \pm 3.73$ & $10.41 \pm 3.79$ & $.090^{*}$ \\
\hline Kapha & $13.39 \pm 4.09$ & $14.21 \pm 3.31 \dagger$ & $.001^{*}$ & $13.56 \pm 3.99$ & $13.39 \pm 3.92$ & $.036^{*}$ \\
\hline
\end{tabular}

Table 2 gives mean scores and standard deviation of yoga (Y) and control (C) group before and after ten days of intervention. Vata has decreased and Pitta, Kapha have increased significantly in Yoga group compared to control group. (*Wilcoxon Signed Ranks Test). Post intervention 
changes in Vata,Pitta and Kapha was significant ,showing both groups are different. $(\dagger$ MannWhiteney U-test $\mathrm{p}<0.05$ )

\section{Discussion}

The study has described the effect of ten days, Yoga personality Development group on children. Scores on Vata scale were reduced after yoga practice. Similarly scores on Pitta and Kapha scale were increased. While in control group pitta has increased, kapha has reduced (table-2). Scores on three subscales before and after were not distributed normally (Kolomogorov-Smirnov Test). Baseline data in two groups were not significant Changes after yoga in yoga group were significant (Wilcoxon Signed Ranks Test). Scores on Vata, Pitta and Kapha after experiment showed two groups are significantly different in changes occurred. (Mann-Whiteny U-test)

Increase in sweating was observed as children practiced dynamic exercises in this study. Sweating is considered as a treatment method to reduce Vata dosha according to Ayurveda classics ${ }^{2}$. A study has shown sweat loss after yoga practice ${ }^{27}$. Vata is associated with rajas and Tamas. Earlier studies have shown rajas and tamas decreases after $\operatorname{yoga}^{28,29}$. The present study has established Vata has reduced after Yoga.

Because of children practiced Asanas increase in the temperature was observed. Pitta has the characteristic of heat. If the temperature of the body, increases pitta increases ${ }^{1-3}$. Earlier studies have discussed the effect of yoga on body temperature and thermoregulation ${ }^{30}$. This study have determined Pitta have increased by integral yoga.

Meditation practiced by children in this study helped to increase Sattva guna. Kapha is predominant is jalamahabhuta, which is associated with Sattva and Tamas guna ${ }^{2}$. Earlier research work $^{33}$ has discussed Kapha correlates with Sattvaguna. Earlier studies have shown Sattva guna increases after yoga $\mathrm{a}^{26,27}$. This investigation has proved the increase in Kapha by Yoga.

The strength of this study it is the first attempt to explore the effect of Yoga Personality Development Camp on tridoshas in children. It has compared yoga group with control group. Researcher was blinded for yoga practice. While, Ayurveda quotes, persons with predominance of single or double doshas will always be diseased and equilibrium state of Tridosha is health. The present result may point, that yoga helps to move towards positive health by changing the states of doshas.

Limitations of the study is though yoga personality camp has resulted in significant changes in tridoshas, randomized sampling method was not applied. Assessor was not blinded. Future studies are required on randomly assigned sample with blinded assessor. And yoga intervention should be given for longer duration to check can yoga bring equilibrium state of doshas? Effect of different types of yoga module e.g. Asanas, Pranayama, Meditation can be studied independently.

\section{Conclusions}

The present study has showed that a ten days practice of integral Yoga has a significant effect on tridoshas in children as compared to control group, of the age group 8-12 years. 


\section{Acknowledgment}

We thank, Dr. Kishore, Dr. Uma, Dr. Aarti Jagannathan, Dr. Subbukrishna, Mariyamma Madam Āyurveda experts in Hubli Āyurveda College, Principal Jayagopal Garodia Rastrotthana school for their support and participation in the study.

\section{References}

[1] Panday GS. Caraka samhita: Hindi commentary, fifth edition: Choukamba publications New Delhi, 1997.

[2] Shastry KA. Sushruta Samhita: Hindi vyakhya, fifteenth edition: Choukamba publications New Delhi, 2002.

[3] Tripati R. Ashtanga sangraha: Hindi commentary, second edition: Choukamba publications New Delhi, 2001.

[4] Hankey A: Establishing the Scientific Validity of Tridosha part 1: Doshas, Subdoshas and Dosha Prakritis; Anc Sci Life. 2010 Jan;29(3):6-18

[5] Dube KC, Kumar A, Dube S: Personality types in Ayurveda; Am J Chin Med. 1983;11(1-4):25-34

[6] White LS: Reducing stress in school-age girls through mindful yoga; J Pediatr Health Care. 2012 Jan-Feb;26(1):45-56. Epub 2011 Mar 2.

[7] Noggle JJ, Steiner NJ, Minami T, Khalsa SB: Benefits of yoga for psychosocial well-being in a US high school curriculum: a preliminary randomized controlled trial; J Dev Behav Pediatr. 2012 Apr;33(3):193-201.

[8] Field T: Exercise research on children and adolescents; Complement Ther Clin Pract. 2012 Feb;18(1):54-9. Epub 2011 May 4.

[9] Khemka SS, Ramarao NH, Hankey A. Effect of integral yoga on psychological and health variables and their correlations: Int J Yoga. 2011 Jul;4(2):93-9.

[10] Berger DL, Silver EJ, Stein RE. Effects of yoga on inner-city children's well-being: a pilot study: Altern Ther Health Med. 2009 Sep-Oct;15(5):36-42.

[11] Rangan R, Nagendra H, Bhat GR. Effect of yogic education system and modern education system on memory: Int J Yoga. 2009 Jul;2(2):55-61.

[12] Krishnan, Sripriya. Personality development through Yoga practices: IJTK Vol.05(4) [October 2006].

[13] Deshpande S, Nagendra HR, Nagarathna R. A randomized control trial of the effect of yoga on Gunas (personality) and Self esteem in normal healthy volunteers: Int J Yoga. 2009 Jan;2(1):1321.

[14] Haffner J, Roos J, Goldstein N, Parzer P, Resch F. The effectiveness of body-oriented methods of therapy in the treatment of attention-deficit hyperactivity disorder (ADHD): results of a controlled pilot study: Z Kinder Jugendpsychiatr Psychother. 2006 Jan;34(1):37-47.

[15] Platania-Solazzo A, Field TM, Blank J, Seligman F, Kuhn C, Schanberg S, Saab P. Relaxation therapy reduces anxiety in child and adolescent psychiatric patients: Acta Paedopsychiatr. 1992;55(2):115-20.

[16] Smith JA, Greer T, Sheets T, Watson S. Is there more to yoga than exercise?: Altern Ther Health Med. 2011 May-Jun;17(3):22-9.

[17] Uma K, Nagendra HR, Nagarathna R, Vaidehi S, Seethalakshmi R. The integrated approach of yoga: a therapeutic tool for mentally retarded children: a one-year controlled study: J Ment Defic Res. 1989 Oct;33 ( Pt 5):415-21

[18] Hadi N, Hadi N. Effects of hatha yoga on well-being in healthy adults in Shiraz, Islamic Republic of Iran: East Mediterr Health J. 2007 Jul-Aug;13(4):829-37. 
[19] Oken BS, Zajdel D, Kishiyama S, Flegal K, Dehen C, Haas M, Kraemer DF, Lawrence J, Leyva J. Randomized, controlled, six-month trial of yoga in healthy seniors: effects on cognition and quality of life: Altern Ther Health Med. 2006 Jan-Feb;12(1):40-7

[20] Khasky AD, Smith JC. Stress, relaxation states, and creativity: Percept Mot Skills. 1999 Apr;88(2):409-16

[21] Schell FJ, Allolio B, Schonecke OW. Physiological and psychological effects of Hatha-Yoga exercise in healthy women: Int J Psychosom. 1994;41(1-4):46-52.

[22] Madanmohan, Mahadevan SK, Balakrishnan S, Gopalakrishnan M, Prakash ES. Effect of six weeks yoga training on weight loss following step test, respiratory pressures, handgrip strength and handgrip endurance in young healthy subjects: Indian J Physiol Pharmacol. 2008 AprJun;52(2):164-70.

[23] Telles S, Singh N. High frequency yoga breathing increases energy -expenditure from carbohydrates. Comment to: Assessment of sleep patterns, energy expenditure and circadian rhythms of skin temperature in patients with acute coronary syndrome: Med Sci Monit. 2011 Sep;17(9):LE7-8.

[24] Suchitra SP.Nagendra HR. Measuring the manasika prakrti of the children: under press.

\footnotetext{
*Corresponding author.

E-mail address: svyasablr@ yahoo.com / www.svyasa.org
} 